\title{
HUBUNGAN USIA IBU, GRAVIDITAS, RIWAYAT PRE-EKLAMPSIA BERAT DI RSUD. KABUPATEN BEKASI PERIODE JUNI 2015- JUNI 2016
}

\author{
Syifa Aulia Luthfiyani ${ }^{1}$, Mariono Reksoprodjo ${ }^{1}$, Anisah $^{1}$ \\ ${ }^{1}$ Fakultas Kedokteran, Universitas Pembangunan Nasional "Veteran" Jakarta, Indonesia \\ E-mail: anisah_bw@yahoo.com
}

\begin{abstract}
ABSTRAK
Indonesia berada diperingkat keempat tertinggi untuk kematian ibu di kawasan ASEAN dan peringkat keenam di kawasan SEAR (South East Asian Region). Pre-eklampsia/eklampsia merupakan penyebab terbesar kedua kematian ibu setelah perdarahan. Penelitian dilakukan untuk menganalisa hubungan dan mencari besarnya risiko antara faktor risiko yaitu usia ibu, graviditas, riwayat preeklampsia dan obesitas terhadap kejadian pre-eklampsia berat di RSUD Kabupaten Bekasi. Penelitian dengan rancangan study case control ini dilakukan dengan melihat data pada rekam medik pasien di RSUD Kabupaten Bekasi periode Juni 2015 -Juni 2016 kemudian dianalisis secara univariat, bivariat dengan Chi-square dan multivariat dengan regresi logistik. Pengambilan sampel menggunakan teknik simple random sampling. Hasil analisis bivariat menunjukan terdapat hubungan bermakna antara graviditas, riwayat pre-eklampsia dan obesitas dengan kejadian pre-eklampsia berat dengan masingmasing nilai $\mathrm{p}=0,022(\mathrm{OR}: 0,251), \mathrm{p}=0,002(6,923)$ dan $\mathrm{p}=0,0001$ (OR: 9,273). Hasil analisis multivariat didapatkan bahwa riwayat pre-eklampsia dan obesitas merupakan faktor yang paling berpengaruh terhadap terjadinya pre-eklampsia berat. Kesimpulan penelitian ini terdapat hubungan bermakna antara graviditas, riwayat pre-eklampsia dan obesitas dengan kejadian pre-eklampsia berat. Primigravida 2,51 kali lebih berisiko, riwayat pre-eklampsia positif 6,923 kali lebih berisiko dan obesitas 9,273 kali lebih berisiko untuk pre-eklampsia berat.
\end{abstract}

Kata Kunci: Graviditas; Pre-eklampsia Berat; Proteinuria; Riwayat Pre-eklampsia.

\begin{abstract}
Pre-eclampsia/Eclampsia is the second largest cause of maternal death after postpartum hemorrhage. There are some risk factors that influence the occurrence of pre-eclampsia/Eclampsia. The aim of the research was to analyze the correlation between risk factors and find the most influence factors to the incidence of severe pre-eclampsia in RSUD District Bekasi. This case control study research done by using secondary data by looking at the data in patient medical records in RSUD District Bekasi period June 2015 - June 2016 and then analyzed using univariate, bivariate with Chi-square and multivariate logistic regression. Sampling method using simple random sampling technique. The results of the bivariate analysis showed there was a significant relationship between gravidity, obesity and history of pre-eclampsia with severe pre-eclampsia with each value of $p=0.022$ (OR: 0.251 ), $p=0.002$ (OR: 6,923) and $p=0.0001$ (OR: 9.273). Multivariate analysis showed that history of pre-eclampsia and obesity are factors that most influence to the occurrence of severe pre-eclampsia. There was a significant relationship between gravidity, history of pre-eclampsia and obesity with severe preeclampsia. Primigravidas 2.51 times higher risk, history of pre-eclampsia positive 6,923 times higher and obesity 9.273 times higher more at risk of developing severe pre-eclampsia.
\end{abstract}

Keywords: History of Pre-eclampsia; Gravidity; Proteinuria; Severe Pre-eclampsia

\section{PENDAHULUAN}

Menurut

World Health

Organization Angka Kematian Ibu (AKI) di dunia pada tahun 2015 adalah 303.000 jiwa, dimana mayoritas dari angka tersebut terjadi pada negara berkembang. Menurut WHO tahun 2015, Indonesia berada di peringkat keempat tertinggi untuk Angka Kematian Ibu dikawasan ASEAN dan peringkat keenam dikawasan SEAR (South East Asian Region). Menurut World Health Organization AKI di Indonesia pada tahun 2015 tercatat 126 per 100.000 kelahiran hidup. Angka tersebut mengalami 
penurunan dibanding tahun 2012 dengan AKI 359 per 100.000 kelahiran hidup. ${ }^{1}$ Namun demikian, angka tersebut jauh lebih tinggi jika dikaitkan dengan target Sustainable Development Goals (SDGs) Indonesia tahun 2030 yaitu menurunkan AKI hingga 90 per 100.000 kelahiran hidup. $^{2}$ Banyak faktor penyebab AKI yang masih tinggi di Indonesia diantaranya adalah perdarahan post partum (26.9\%), pre-eklampsia/eklampsia (23\%), infeksi (11\%), komplikasi purpureum (8\%), trauma obstetrik (5\%), emboli obstetrik (8\%), aborsi (8\%) dan lain-lain (10.9\%). Di Indonesia, pre-eklampsia/eklampsia masih merupakan sebab utama kematian ibu dan sebab utama kematian perinatal yang tinggi. $^{3}$

Jawa Barat menjadi salah satu provinsi yang berkontribusi besar terhadap tingginya AKI di Indonesia. Menurut Kementerian Kesehatan Republik Indonesia provinsi Jawa Barat merupakan provinsi dengan AKI tertinggi pada tahun 2015 yaitu sebesar 823 kasus. ${ }^{4}$ Survei yang dilaksanakan Badan Pusat Statistik Provinsi Jawa Barat tahun 2012 menunjukan bahwa AKI Provinsi Jawa Barat sebesar 86,3 per 100.000 kelahiran hidup. ${ }^{5}$ Berdasarkan Laporan Kesehatan Provinsi Jawa Barat, kabupaten Bekasi merupakan salah satu kabupaten di Provinsi Jawa Barat yang masuk ke dalam sepuluh besar penyumbang AKI di provinsi Jawa Barat, yaitu dengan AKI pada tahun 2011 adalah 26 per 100.000 kelahiran hidup, tahun 2012 mengalami peningkatan menjadi 44 per 100.000 kelahiran hidup dan tahun 2013 menjadi 36 per 100.000 kelahiran hidup. ${ }^{5}$ RSUD Kabupaten Bekasi merupakan salah satu Rumah Sakit rujukan utama di daerah kabupaten Bekasi. Data AKI di RSUD Kabupaten Bekasi tahun 2011 sebanyak 108 kasus dengan penyebab kematian ibu terbanyak adalah pre-eklampsia/eklampsia. Selain itu, didapatkan data penderita preeklampsia berat di RSUD Kabupaten Bekasi tahun 2011 sebanyak 119. ${ }^{6}$

Mengingat Angka Kematian Ibu yang disebabkan oleh pre-eklampsia cukup tinggi di kabupaten Bekasi, maka perlu dilakukan pencegahan terhadap terjadinya pre-eklampsia. Langkah awal pencegahan yang dapat dilakukan adalah dengan mengetahui faktor risiko terjadinya preeklampsia. Untuk itu, penelitian ini dapat menjadi bahan informasi mengenai faktor risiko terjadinya pre-eklampsia. Dengan demikian dapat mengurangi risiko terjadinya pre-eklampsia dan menurunkan Angka Kematian Ibu di Indonesia khususnya di Kabupaten Bekasi.

\section{METODE PENELITIAN}

Penelitian dilakukan di RSUD Kabupaten Bekasi pada bulan Januari 2017. Penelitian bersifat analitik observasional. Pengumpulan data dilakukan dengan melihat data pada rekam medik pasien di RSUD Kabupaten Bekasi periode Juni 2015-Juni 2016. Teknik sampling yang digunakan adalah teknik simple random sampling dengan pendekatan studi kasus kontrol. Populasi penelitian ini adalah semua ibu hamil atau bersalin yang tercatat di RSUD Kabupaten Bekasi. Sampel yang digunakan pada penelitian ini adalah pasien yang didiagnosis pre-eklampsia berat baik yang berobat, dirawat atau pernah dirawat di RSUD Kabupaten Bekasi yang memenuhi kriteria inklusi dan eksklusi dari bulan Juni 2015-Juni 2016. Sedangkan kontrol adalah ibu hamil atau bersalin yang tidak mengalami pre-eklampsia di RSUD Kabupaten Bekasi yang memenuhi kriteria inklusi dan eksklusi dari bulan Juni 2015 sampai Juni 2016. Analisis data pada penelitian ini terdiri dari analisis univariat, bivariat dengan uji Chi-square serta multivariat menggunakan uji regresi logistik.

HASIL

\section{Analisis Univariat}

Distribusi Frekuensi Kejadian Preeklampsia Berat di RSUD Kabupaten Bekasi Periode Juni 2015- Juni 2016 
Tabel 1. Distribusi frekuensi kejadian preeklampsia berat

\begin{tabular}{ccc}
\hline PEB & $\begin{array}{c}\text { Frekuensi } \\
(\mathbf{f})\end{array}$ & $\begin{array}{c}\text { Persentase } \\
(\boldsymbol{\%})\end{array}$ \\
\hline Ya & 28 & 50 \\
Tidak & 28 & 50 \\
Jumlah & 56 & 100 \\
\hline
\end{tabular}

Sumber : Data Catatan Rekam Medik RSUD

Kabupaten Bekasi Juni 2015-Juni 2016

Distribusi Frekuensi Graviditas Ibu di RSUD Kabupaten Bekasi Periode Juni 2015 - Juni 2016

Tabel 2. Distribusi Frekuensi Graviditas

\begin{tabular}{ccc}
\hline Graviditas & $\begin{array}{c}\text { Frekuensi } \\
\text { (f) }\end{array}$ & $\begin{array}{c}\text { Persentase } \\
(\boldsymbol{\%})\end{array}$ \\
\hline Primigravida & 18 & 32.1 \\
Multigravida & 38 & 67.9 \\
Jumlah & 56 & 100 \\
\hline
\end{tabular}

Sumber : Data Catatan Rekam Medik RSUD Kabupaten Bekasi Juni 2015-Juni 2016

Distribusi Frekuensi Usia Ibu di RSUD Kabupaten Bekasi Periode Juni 2015- Juni 2016

Tabel 3. Distribusi frekuensi Usia Ibu

\begin{tabular}{ccc}
\hline Usia & $\begin{array}{c}\text { Frekuensi } \\
(\mathbf{f})\end{array}$ & $\begin{array}{c}\text { Persentase } \\
(\boldsymbol{\%})\end{array}$ \\
\hline$<20 \&>35$ th & 14 & 25 \\
$20-35$ th & 42 & 75 \\
Jumlah & 56 & 100 \\
\hline
\end{tabular}

Sumber : Data Catatan Rekam Medik RSUD Kabupaten Bekasi Juni 2015-Juni 2016

Distribusi Frekuensi Riwayat Preeklampsia pada Ibu di RSUD Kabupaten Bekasi Periode Juni 2015- Juni 2016

Tabel 4. Distribusi Frekuensi Riwayat Preeklampsia

\begin{tabular}{ccc}
\hline $\begin{array}{c}\text { Riwayat } \\
\text { Pre- } \\
\text { eklampsia }\end{array}$ & $\begin{array}{c}\text { Frekuensi } \\
\text { (f) }\end{array}$ & Persentase (\%) \\
\hline Ya & 19 & 34 \\
Tidak & 37 & 66 \\
Jumlah & 56 & 100 \\
\hline
\end{tabular}

Sumber : Data Catatan Rekam Medik RSUD Kabupaten Bekasi Juni 2015-Juni 2016
Distribusi Frekuensi Kejadian Obesitas pada Ibu di RSUD Kabupaten Bekasi Periode Juni 2015- Juni 2016

Tabel 5. Distribusi Frekuensi Kejadian Obesitas

\begin{tabular}{ccc}
\hline Obesitas & $\begin{array}{c}\text { Frekuensi } \\
(\mathbf{f})\end{array}$ & $\begin{array}{c}\text { Persentase } \\
(\boldsymbol{\%})\end{array}$ \\
\hline Ya & 21 & 37.5 \\
Tidak & 35 & 62.5 \\
Jumlah & 56 & 100 \\
\hline
\end{tabular}

Sumber : Data Catatan Rekam Medik RSUD Kabupaten Bekasi Juni 2015-Juni 2016

Analisis Bivariat

Distribusi Responden Menurut Usia Ibu, Graviditas, Riwayat Pre-eklampsia dan Obesitas dengan Kejadian Pre-eklampsia berat dapat dilihat pada tabel 6

\section{PEMBAHASAN}

Berdasarkan tabel 6 dapat diketahui hubungan serta nilai OR antara usia ibu, graviditas, riwayat pre-eklampsia dan obesitas dengan kejadian pre-eklampsia berat. Didapatkan bahwa rata-rata responden yang mengalami pre-eklampsia berat terjadi pada usia aman reproduksi seperti yang direkomendasikan oleh Departemen Kesehatan (2000) yaitu usia 20-35 tahun. Berdasarkan hasil uji statistik pada penelitian ini didapatkan bahwa tidak terdapat hubungan yang bermakna antara usia ibu dengan kejadian pre-eklampsia berat, hal ini dapat terlihat dari nilai $\mathrm{p}>0,05$ yaitu $\mathrm{p}=1,000$. Artinya, pre-eklampsia berat dapat terjadi pada berbagai kategori usia. Terdapat ketidaksesuaian antara teori dengan kejadian pada penelitian dilapangan bahwa usia ibu <20 tahun dan >35 tahun dapat mempengaruhi kejadian preeklampsia berat pada kehamilan. Hal ini disebabkan oleh karena pada responden usia 20-35 tahun dimungkinkan terdapat faktor risiko lain seperti riwayat preeklampsia pada orang tua yang tidak dapat peneliti kendalikan pada penelitian ini. Riwayat pre-eklampsia pada orang tua cukup berpengaruh terhadap kejadian preeklampsia berat. Hal ini diperkuat oleh penelitian Chesley dan Cooper (1986) 
dalam Cunningham (2014) yang menyimpulkan bahwa preeklampsia/eklampsia bersifat sangat diturunkan. ${ }^{7}$ Tidak terdapat hubungan yang bermakna antara usia ibu dengan kejadian pre-eklampsia berat pada penelitian ini sesuai dengan penelitian yang dilakukan oleh Karima (2015). ${ }^{8}$ Lain halnya dengan penelitian yang dilakukan oleh Rozikhan usia berisiko yaitu $<20$ tahun dan $>35$ tahun diharapkan untuk melakukan antenatal care lebih sering dibandingkan dengan ibu yang hamil pada usia 20-35 tahun.

Sementara itu, didapatkan bahwa rata-rata responden yang mengalami preeklampsia berat adalah seorang multipara. Namun demikian berdasarkan hasil analisis dengan uji statistik dan perhitungan nilai Odds Ratio (OR) dengan derajat kepercayaan (CI) 95\% didapatkan bahwa terdapat hubungan yang bermakna antara graviditas dengan kejadian pre-eklampsia berat. Hal ini dapat terlihat dari nilai $p<0,05$ yaitu $\mathrm{p}=0,022$. Artinya, pre-eklampsia berat cenderung terjadi pada kehamilan pertama. Sementara itu, didapatkan Nilai $\mathrm{OR}=0,251$ menunjukan bahwa ibu primigravida memiliki risiko 2,51 kali lebih besar untuk mengalami pre-eklampsia berat dibandingkan dengan ibu multigravida. Hal ini disebabkan oleh karena pada kehamilan pertama pembentukan blocking antibodi terhadap antigen janin atau plasenta belum
(2007) dan Yulianti (2008) didapatkan hasil bahwa terdapat hubungan yang signifikan antara usia ibu dengan kejadian preeklampsia berat sesuai dengan teori yang banyak dikemukakan. ${ }^{9,10}$ Untuk itu, ibu diharapkan hamil pada usia reproduktif yaitu usia 20-35 tahun dan menghindari kehamilan pada usia $<20$ tahun dan $>35$ tahun. Jika ibu hamil pada

sempurna sehingga timbul respon imun berupa komplek imun yang merugikan bagi plasenta atau janin. ${ }^{3}$ Selain itu, primigravida sering mengalami stres dalam menghadapi kehamilan dan persalinan. Stres yang terjadi pada primigravida dapat menyebabkan peningkatan pelepasan corticotropic-releasing hormone (CRH) oleh hipotalamus yang kemudian menyebabkan peningkatan kortisol. Efek kortisol adalah mempersiapkan tubuh untuk berespon terhadap semua stresor dengan meningkatkan respons simpatis. ${ }^{11} \mathrm{Hal}$ ini sejalan dengan penelitian yang dilakukan oleh Rozikhan (2007) dan Yani dalam Karima (2015) didapatkan bahwa paritas memiliki hubungan terhadap kejadian preeklampsia berat. ${ }^{8,9}$ Lain halnya dengan penelitian yang dilakukan oleh Karima (2015) dan Yulianti (2008) didapatkan hasil bahwa paritas tidak berhubungan secara bermakna dengan kejadian pre-eklampsia berat. ${ }^{8,10}$

Tabel 6. Distribusi Responden Menurut Usia Ibu, Graviditas, Riwayat Pre-eklampsia dan Obesitas dengan Kejadian Pre-eklampsia berat

\begin{tabular}{|c|c|c|c|c|c|c|c|}
\hline & & \multicolumn{4}{|c|}{ Pre-eklampsia Berat } & \multirow{3}{*}{$P$} & \multirow{3}{*}{ OR CI (95\%) } \\
\hline & & \multicolumn{2}{|c|}{ Tidak } & \multicolumn{2}{|c|}{ Ya } & & \\
\hline & & $\mathrm{N}$ & $\%$ & $\mathrm{~N}$ & $\%$ & & \\
\hline \multirow[t]{3}{*}{ Usia } & $<20 \&>35$ & 7 & 25 & 7 & 25 & \multirow{3}{*}{1,000} & \multirow{2}{*}{1} \\
\hline & $20-35$ & 21 & 75 & 21 & 75 & & \\
\hline & Total & 28 & 100 & 28 & 100 & & \\
\hline \multirow[t]{3}{*}{ Graviditas } & Primigravida & 13 & 46,4 & 5 & 17,8 & \multirow{2}{*}{0,022} & \multirow{2}{*}{0,251} \\
\hline & Multigravida & 15 & 53,6 & 23 & 83,2 & & \\
\hline & Total & 28 & 100 & 28 & 100 & & \\
\hline \multirow{3}{*}{$\begin{array}{l}\text { Riwayat } \\
\text { Pre- } \\
\text { eklampsia }\end{array}$} & Ya & 4 & 14,2 & 15 & 53,6 & \multirow{3}{*}{0,002} & \multirow{3}{*}{6,923} \\
\hline & Tidak & 24 & 85,8 & 13 & 46,4 & & \\
\hline & Total & 28 & 100 & 28 & 100 & & \\
\hline
\end{tabular}




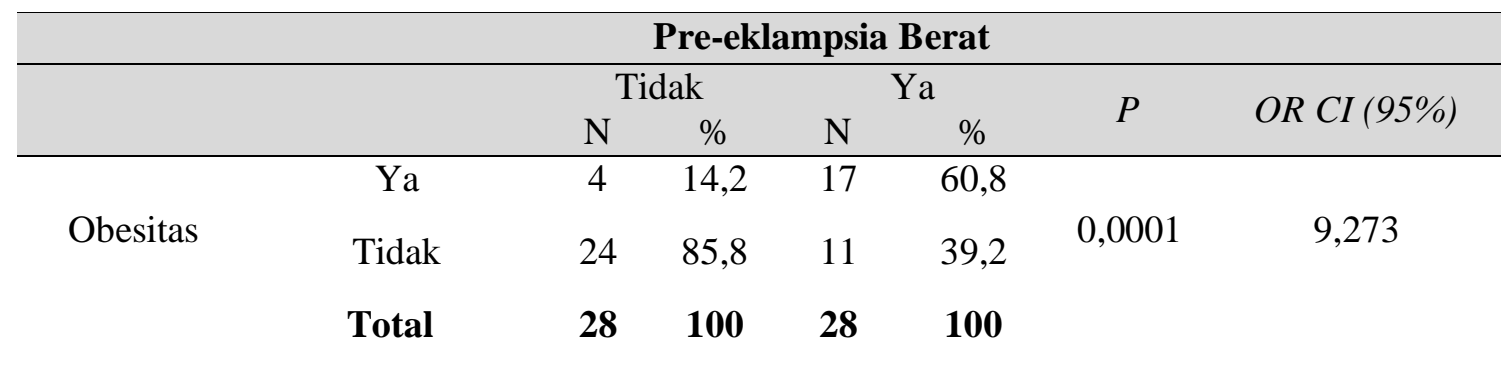

Sumber : Data Catatan Rekam Medik RSUD Kabupaten Bekasi Juni 2015-Juni 2016

Berdasarkan tabel analisis diatas dapat diketahui bahwa responden yang mengalami pre-eklampsia berat mayoritas memiliki riwayat pre-eklampsia pada kehamilan sebelumnya. Setelah dilakukan analisis didapatkan bahwa terdapat hubungan yang bermakna antara riwayat pre-eklampsia dengan kejadian preeklampsia berat. Hal ini dapat terlihat dari nilai $\mathrm{p}<0,05$ yaitu $\mathrm{p}=0,002$. Artinya, preeklampsia berat cenderung terjadi pada ibu dengan riwayat pre-eklampsia sebelumnya. Selain itu, didapatkan Nilai OR $=6,923$ menunjukan bahwa ibu dengan riwayat preeklampsia sebelumnya memiliki risiko 6,923 kali lebih besar untuk mengalami preeklampsia berat dikehamilan selanjutnya dibandingkan dengan ibu yang tidak memiliki riwayat pre-eklampsia sebelumnya. Hal ini disebabkan oleh karena pre-eklampsia diyakini dapat menginduksi perubahan vaskular dan metabolisme yang bersifat irreversibel, perubahan irreversibel tersebut diyakini dapat meningkatkan risiko terjadinya hipertensi dan cardio vascular disease di masa yang akan datang. ${ }^{12} \mathrm{Hal}$ ini sesuai dengan penelitian yang dilakukan oleh Yulianti (2008) didapatkan hasil bahwa ibu hamil dengan riwayat preeklampsia sebelumnya berisiko mengalami pre-eklampsia berat/eklampsia $20 \%$ lebih tinggi pada kehamilan berikutnya. ${ }^{10}$ Melakukan pemeriksaan kehamilan atau antenatal care secara rutin sesuai yang dijadwalkan oleh bidan atau tenaga kesehatan yang menangani sangat dianjurkan agar dapat dikenali sedini mungkin risiko seperti riwayat preeklampsia sebelumnya, tanda dan gejala pre-eklampsia berat.
Ditemukan pula pada kelompok responden yang mengalami pre-eklampsia berat bahwa proporsi ibu obesitas lebih banyak dibandingkan dengan ibu nonobese. Berdasarkan hasil analisis didapatkan bahwa terdapat hubungan yang bermakna antara obesitas (BMI $\geq 30$ ) dengan kejadian pre-eklampsia berat. Hal ini dapat terlihat dari nilai $\mathrm{p}<0,05$ yaitu $\mathrm{p}=$ 0,0001 . Artinya, pre-eklampsia berat cenderung terjadi pada ibu dengan status gizi obese. Sementara itu, didapatkan Nilai $\mathrm{OR}=9,273$ menunjukan bahwa ibu obesitas memiliki risiko 9,237 kali lebih besar untuk mengalami pre-eklampsia berat dibandingkan dengan ibu non-obese. Hal ini disebabkan oleh karena ibu hamil dengan status gizi obesitas memiliki jaringan lemak berlebih. Jaringan lemak tersebut akan menghasilkan CRP (Protein C-Reactif) dan sitokin inflamasi (IL-6) yang lebih pula. Kenaikan CRP dan IL-6 akan memberikan kontribusi terhadap kejadian oksidatif stress endotel sehingga akan menimbulkan disfungsi endotel. ${ }^{13}$ Selain itu, hal ini sejalan dengan penelitian yang dilakukan oleh Puspitasari (2009) dan Wingardi dalam Puspitasari (2009) didapatkan bahwa obesitas saat kehamilan memiliki hubungan terhadap kejadian pre-eklampsia berat. ${ }^{14}$ Lain halnya dengan penelitian yang dilakukan oleh Karima (2015) dan Yulianti (2008) didapatkan hasil bahwa paritas tidak berhubungan secara bermakna dengan kejadian pre-eklampsia berat. ${ }^{8,10}$ Untuk itu, ibu hamil dan ibu yang akan merencanakan kehamilan diharapkan dapat mengatur pertambahan berat badan selama kehamilan dan menjelang kehamilan sesuai dengan anjuran tenaga kesehatan untuk mencegah 
timbulnya keadaan patologis seperti preeklampsia berat.

\section{Analisis Multivariat}

Dari seleksi analisis bivariat dengan uji Chi-square didapatkan variabel yang memiliki $\mathrm{p}<0,25$ dan akan dimasukkan dalam uji multivariat adalah variabel graviditas, riwayat pre-eklampsia dan obesitas. Sedangkan variabel usia ibu tidak dimasukkan karena p>0,25 yaitu 1,000.

Tabel 7. Hasil Seleksi Bivariat Variabel Independen

\begin{tabular}{cc}
\hline Variabel & Nilai $p$ \\
\hline Graviditas & 0,022 \\
Riwayat Pre-eklampsia & 0,002 \\
Obesitas & 0,0001
\end{tabular}

Dari tabel 8 pada halaman selanjutnya dapat terlihat bahwa pada langkah pertama variabel yang memiliki nilai $p$ paling besar adalah variabel primigravida yaitu $p=0,196$ sehingga primigravida sudah tidak lagi tercantum pada langkah kedua. Dari hasil langkah kedua dapat diketahui variabel yang berpengaruh terhadap kejadian preeklampsia berat adalah riwayat preeklampsia dan obesitas. Kekuatan hubungan dapat dilihat dari nilai OR masing-masing variabel. Persamaan yang didapatkan dari hasil penelitian ini adalah :

$$
\begin{aligned}
& y=\text { Konstanta }+\mathrm{a}_{1} \mathrm{x}_{1}+\mathrm{a}_{2} \mathrm{x}_{2} \\
& \mathrm{y}=-7,52-1,334(0)+1,793(0) \\
& \mathrm{y}=-7,52
\end{aligned}
$$

Aplikasi dari persamaan yang diperoleh adalah untuk memprediksi probabilitas seorang ibu dengan riwayat pre-eklampsia dan mengalami obesitas untuk mengalami pre-eklampsia berat dengan menggunakan rumus sebagai berikut : $\mathbf{p}=\mathbf{1 /}\left(\mathbf{1}+\mathrm{e}^{-\mathbf{y}}\right)$. Dengan demikian dapat dicari probabilitas untuk terjadinya pre-eklampsia berat dengan rumus sebagai berikut :

$$
\begin{aligned}
& p=1 /\left(1+2,7^{7,52}\right) \\
& p=0,005
\end{aligned}
$$

Dengan demikian probabilitas ibu hamil dengan riwayat pre-eklampsia pada kehamilan sebelumnya dan saat ini mengalami obesitas untuk mengalami pre-

\begin{tabular}{|c|c|c|c|c|}
\hline & Konstanta & $-7,52$ & 0,249 & \\
\hline & Variabel & Koefisien & $P$ & (IC 95\%) \\
\hline \multirow[t]{4}{*}{ Langkah 1} & Primigranida & 0,920 & 0,196 & $\begin{array}{c}2,509 \\
(0,622-10,130)\end{array}$ \\
\hline & $\begin{array}{c}\text { Riwayat Pre-eklampsia } \\
\text { positif }\end{array}$ & $-1,099$ & 0,145 & $\begin{array}{c}0,333 \\
(0,076-1,459)\end{array}$ \\
\hline & Obesitas & 1,784 & 0,013 & $\begin{array}{c}5,953 \\
(1,455-24,352)\end{array}$ \\
\hline & Konstanta & $-1,110$ & 0,126 & \\
\hline \multirow[t]{2}{*}{ Langkah 2} & $\begin{array}{c}\text { Riwayat pre-eklampsia } \\
\text { positif }\end{array}$ & $-1,334$ & 0,066 & $\begin{array}{c}0,263 \\
(0,064-1,091)\end{array}$ \\
\hline & Obesitas & 1,793 & 0,011 & $\begin{array}{c}6,009 \\
(1,509-23,931)\end{array}$ \\
\hline
\end{tabular}
eklampsia berat adalah sebesar 5\%.

Tabel 8. Hasil analisis multivariat regresi logistik antara variabel Graviditas, riwayat pre-eklampsia dan obesitas

Sedangkan jika ibu hamil tersebut memiliki riwayat pre-eklampsia pada kehamilan sebelumnya tetapi saat ini tidak mengalami obesitas probabilitasnya untuk mengalami pre-eklampsia berat adalah sebagai berikut :

$$
\begin{aligned}
& y=-7,52-1,334(0)+1,793(1) \\
& y=-5,727 \\
& p=1 /\left(1+2,7^{5,727}\right) \\
& p=0,003
\end{aligned}
$$

Probabilitas ibu hamil dengan riwayat preeklampsia pada kehamilan sebelumnya tetapi saat ini tidak mengalami obesitas untuk mengalami pre-eklampsia berat adalah sebesar $3 \%$.

Sedangkan jika ibu hamil tersebut tidak memiliki riwayat pre-eklampsia pada kehamilan sebelumnya tetapi saat ini mengalami obesitas probabilitasnya untuk mengalami pre-eklampsia berat adalah sebagai berikut :

$$
\begin{aligned}
& y=-7,52-1,334(1)+1,793(0) \\
& y=-8,844 \\
& p=1 /\left(1+2,7^{8,844}\right) \\
& p=0,0001
\end{aligned}
$$


Probabilitas ibu hamil yang tidak memiliki riwayat pre-eklampsia pada kehamilan sebelumnya tetapi saat ini mengalami obesitas untuk mengalami preeklampsia berat adalah sebesar $1 \%$.

\section{KESIMPULAN}

a. Gambaran distribusi penderita preeklampsia berat dalam penelitian ini adalah berusia 20-35 tahun sebanyak $75 \%$, multigravida sebanyak $67,9 \%$ memiliki riwayat pre-eklampsia sebanyak $53,6 \%$ dan obesitas sebanyak $60,8 \%$.

b. Faktor yang memiliki hubungan bermakna terhadap kejadian preeklampsia berat adalah primigravida, riwayat pre-eklampsia dan obesitas dengan $\mathrm{BMI} \geq 30$.

c. Faktor risiko riwayat pre-eklampsia dan obesitas masih berhubungan secara signifikan dengan kejadian preeklampsia berat saat di analisis dengan metode regresi logistik backward.

d. Ibu yang memiliki riwayat preeklampsia dan obesitas memiliki peluang 5\% untuk mengalami preeklampsia berat.

e. Ibu hamil dengan riwayat preeklampsia pada kehamilan sebelumnya tetapi saat ini tidak mengalami obesitas berpeluang 3\% untuk mengalami preeklampsia.

f. Ibu hamil yang tidak memiliki riwayat pre-eklampsia pada kehamilan sebelumnya tetapi saat ini mengalami obesitas berpeluang $1 \%$ untuk mengalami pre-eklampsia berat.

\section{DAFTAR PUSTAKA}

1. World Health Organization, Global Maternal Mortality Rate, World Health Organization. 2015.

2. The United Nations Development Programme, Sustainable Development Goals 2030. World Health Organization. 2015.

3. Djannah, Nur S., 'Gambaran epidemiologi kejadian pre eklampsia/eklampsia di RSU PKU
Muhammadiyah Yogyakarta tahun 2007-2009. 2010; 13(4): 378-385. Available from (http://lib.fk. undip.ac.id/index.php?mod=opaq.a rtikel.form\&page=165\&id_artikel= 9548). [Accessed 1 oktober $1^{\text {st }}$ ,2016].

4. Kementerian Kesehatan Republik Indonesia 2015, Profil Kesehatan Indonesia 2015, Kementerian Kesehatan Republik Indonesia, Jakarta. 2015.

5. Departemen Kesehatan Provinsi Jawa Barat 2012, Profil Kesehatan Provinsi Jawa Barat Tahun 2012. Departemen Kesehatan Provinsi Jawa Barat, Bandung. 2012.

Profil RSUD Kabupaten Bekasi 2016, Available from http://.rsud.bekasikab.go.id/web/ind ex.php/home/profilRSUD.

[Accessed January 25, 2017].

6. Cunningham, F.G. et.al, Williams Obstetrics. 24th Ed. Prentice Hall International Inc. Connecticut: Appleton and Lange. 2014.

7. Karima, M, Hubungan faktor risiko dengan kejadian pre-eklampsia berat di RSUP dr. M. Djamil Padang . 2013;v4(3). Available from http://jurnal.fk.unand.ac.id/index.p p/jka/article/download/299/281. pdf. [Accessed September 2, 2016].

8. Rozikhan. faktor-faktor risiko terjadinya pre-eklampsia Berat di rumah sakit dr. H.Soewondo Kendal. 2007; 6 (1). Available from http://eprints.undip.ac.id/18342/1/R OZIKHAN.pdf. [Accessed on September 3, 2016].

9. Yulianti, L. Pre-eklampsia Berat di RSUD Bayu Asih Purwakarta Tahun 2003-2004. 2008; 3(1): 3944. Available from http://jurnalkesmas. ui. ac.id/index. php/kesmas/article/ view/241.pdf). [Accessed on September 2, 2016].

10. Pratiwi Ika. 2015. Hubungan paritas dengan kejadian preeklampsia pada ibu hamil di RSUD Wonosari. 2015; 
5(3). Available from http://opac. unisayogya.ac.id/550/1/NASKAH2 PUBLIKASI IKA PRATIWI . 01410104463.pdf) [Accessed on September 4, 2016].

11. Garovic, D, Preeclampsia and the Future Risk of Hypertension: The Pregnant Evidence, National Institute of Health. 2013; 2.
12. Roberts, 'The Role of Obesity in Pre-eclampsia', National Institute of Health. 2011; 2-3.

13. Puspitasari, Faktor-faktor yang berhubungan dengan kejadian preeklampsia pada ibu hamil di RSUP Dr.Kariadi Semarang 2007. 2009; 7(5). Available from http://lib. unnes.ac.id/6991/1/5726.pdf. [Accessed on september 2, 2016]. 